\title{
Historical Trends and Transitions in Credit Risk Management of Chinese Commercial Banks
}

\author{
Bhabani Shankar Nayak ${ }^{1} \&$ Jia $\mathrm{Xu}^{2}$ \\ ${ }^{1}$ Senior Lecturer in Business Strategy, Coventry Business School, Coventry University, UK \\ ${ }^{2}$ Vice President, Anhui Rende Chuanghe Investment Management Co. Ltd, Anhui, China \\ Correspondence: Bhabani Shankar Nayak, Senior Lecturer in Business Strategy, Coventry Business School, \\ Coventry University, UK.
}

Received: August 22, 2018

Accepted: September 7, 2018

Online Published: September 12, 2018

doi:10.5430/ijba.v9n5p96

URL: https://doi.org/10.5430/ijba.v9n5p96

\begin{abstract}
The paper outlines different trends and transitions in the history of credit risk management of Chinese commercial banks. By critically reviewing different stages of credit management and its historical evolution, it helps in understanding the nature of subjective challenges faced by Chinese commercial banks to manage credit risks. It reviews post reform policies in particularly after 1978 to locate the policy transitions and trajectories of credit risk management of commercial banks in China. It helps to understand the problems and prospects of effective credit management of risks by Chinese commercial banks. It argues that Chinese commercial banks are facing greater challenges in managing risk after the entry of foreign banks to China. Therefore, it is important for the commercial banks in China to develop its own credit management mechanisms within the context of Chinese banking environment.
\end{abstract}

Keywords: credit, risk, management, commercial banks, China

\section{Introduction}

Banking operations have two aspects: issuing loans and taking deposits from the public. The lending and borrowing process contains a great deal of uncertainty. It is difficult to avoid risk in the traditional lending activity of banks because it is impossible to forecast the future solvency of lenders (Freixas and Rochet, 2008). Alman (2012) divided the financial risks which occur in financial institutions into three types: credit risk, market risk and liquidity risk. One of the most important risks which banks encounter is the credit risk, which is defined as the potential that a borrower will fail to meet repayment liability according to the agreed terms (Crouhy, Galai and Mark, 2014). Theoretically, there are three types of credit risk: the first is credit default risk arising from a borrower being unable to pay the loan obligations in full or the loan obligations go ninety days past the agreed date of payment. The second is concentration risk which is linked to the exposure to an individual or group with the possibility of producing losses large enough to threaten a bank's core operations. The third is country risk originating from when a sovereign state stops foreign currency payment or a sovereign state defaults on its loan obligations (Grundke, 2010). With the development of modern finance, Research into credit risk has changed from the traditional qualitative analysis into quantitative credit risk management models (Tsai et al, 2016). The management of credit risk is mainly reflected in the process of lending, which contains a range of requirements on pre-loan investigation, lending principle, approval of loan and after-loan management (Hilscher and Wilson, 2016).

With regard to the Asian crisis in the late 1990s and the 2008 global financial crisis, the lax standards of loan business managers in monitoring the loans were the main cause and a more efficient credit risk management was seen as the solution (Deventer, Imai and Mesler, 2005). Similarly, credit risk has often been the main reason for many difficult banking crises in developing countries (Blanchard, Dell'Ariccia and Mauro, 2010). Because of the high competition in the banking sector of developing economies, banks made loans without analysing the borrowers' credibility which resulted in a large amount of non-performing loans (Hasan, Wachtel and Zhou, 2009).

It is hard not to mention the predomination of China in the rise of developing countries. Its Gross Domestic product (GDP) of $\$ 11$ trillion in 2016 signals China as the second most prosperous economy only just behind the USA. Chart 1 shows that during the last five years, the GDP growth rate has regularly been higher than $6.7 \%$ according to 
the National Bureau of Statistics of China (2017). This fast-growing economy has led to a remarkable development in commercial banking. In 2016, the China Banking Regulatory Commission (CBRC) reported that the total amount of domestic and foreign currency assets in Chinese banking sector was 232 trillion and 250 billion yuan while the non-performing loan ratio of commercial banks was $1.74 \%$ (Data.worldbank.org, 2017). However, the real level of bad debt in China is ten times the official amount according to the rating agency Fitch. Compared to the international non-performing loan ratios which were all below 5\% from 2011 to 2015 in Chart 2, there has been a large gap in credit risk management between Chinese commercial banks and international commercial banks (Edwin,2017).

\section{Historical Transitions and Trends in Credit Management of Commercial Banks in China}

Although banking can be traced back to the temples of Babylon where money exchange took place in 2000 B.C., it is generally believed that banks actually appeared in Venice, Italy, in 1580, and modern banks began in 1694 when the Bank of England was founded. In the late Ming Dynasty, there were three kinds of financial institutions that controlled the loan business of the country: Piaohao, Qianzhuang and foreign banks. Customers of Piaohao and Qianzhuang were different. Owners of large companies and governors preferred Piaohao, but owners of small firms and local citizens tended to use Qianzhuang. After the Opium War, some foreign banks entered the financial business in China and made huge profits with their privileges. The first foreign bank was the Bank of England who entered into China in 1845. In 1897, the Chinese Commercial Bank started as the first domestic bank (Wilson and Yang, 2016).

In the 1930s, the old Chinese ruling Kuomintang regime established the financial system including four banks, two bureaus and one coffer (the Central Bank, China Bank, Bank of Communications, Farmers' Bank, Chinese Central Trust Bureau, Postal Remittance Bureau and the Central Cooperative Coffer). This system also included provincial, city, county and government-private joint banks (Hsiao-yi, 1982). In addition, there was a group of private banks and Qianzhuang founded by national capitalists in China, about one third of which were concentrated in Shanghai, but most of them were not large and speculative and played a very limited role in the loan business (Wilson and Yang, 2016).

With the end of the Second World War and the victory of Chinese People's Liberation War, the new Chinese government established the People's Bank of China and began issuing Renminbi in 1948. Meanwhile, all foreign banks in China were abolished and foreign currencies were forbidden. Since then, China under the planned economy system has formed the universal banking system by the People's Bank of China while other banks were components of it. The People's Bank of China has become a commercial bank that handles deposits, loans and exchange transactions, and also served as the central bank (Li, 1995). However, during the "Cultural Revolution", under the guidance of the "left" ideology, the independence of banks gradually disappeared. For example, the People's Bank of China became an affiliate of the Ministry of Finance. Many leaders confused financial funds with credit funds and carried out a lot of actions against the economic laws (Chen, 2016).

In 1978, the Communist Party of China comprehensively corrected the 'Cultural Revolution' and its previous 'left' ideological mistakes in the third Plenary Session of the 11th Central Committee, which led to a new period of reform and 'opening up'. Under the guidance of Deng Xiaoping, the credit risk management of Chinese banking industry gradually went through the following four stages (Mohanty, 1998).

\subsection{Credit Risk Management Under Early Reform Period From 1978 to 1983}

In 1978, although the People's Bank of China restored its status as an independent ministerial unit, its dual functions of commercial banks and central banks did not change. Under the guidance of the policy of reform and 'opening up' in 1979, several state-owned specialized banks were separated from the People's Bank of China. To be specific, the Agricultural Bank of China was in charge of rural financial business and the Bank of China was responsible for foreign trade credit and foreign exchange. The China Construction Bank is responsible for long-term investment and loan business (Wang, 2003). In 1983, the Industrial and Commercial Bank of China took over the services of credit and savings from the People's Bank of China. China had basically formed a banking system consisting of the Central Bank as the leader and four major national specialized banks as the backbone.

During this period, China's economy was running and developing in accordance with the typical product-related economic system. This is a highly centralized, administrative based, capital supply oriented system. Under the traditional product economy system, credit risk is assumed by the state. In addition to the fight against corruption and the misappropriation of financial funds, credit risk management mainly relies on the allocation of mandatory loan plans. As long as enterprises are not bankrupt, banks can make loans as planned. Therefore, the risk concept of both society and banks is weak (Long and Zhang, 2001). 


\subsection{Credit Risk Management Under the Planned Economy in China From 1984 to 1993}

Since 1984, China's banking system has expanded rapidly in order to promote the transformation from planned economy to market economy. The Central Bank has introduced a policy - 'the four national banks can choose enterprises as clients and enterprises can choose banks for loan applications'. This encouraged competition between the four national banks, thus breaking the traditional pattern of the unified collection of bank funds and unified expenditure. The four state-owned banks began to extend their business to the countryside, providing loans for the booming township enterprises (Zhang et al., 2016).

In 1986, Deng Xiaoping called for greater steps in financial reform to make banks become the real commercial banks. So, what did this mean? In the initial stages of reform and 'opening up', the four national specialized banks were engaged in both government-led credit business and market-driven credit business. Then, the National Development Bank, the Export-Import Bank of China, and the Agricultural Development Bank of China were set up to deal with the entire government-led loan business, which separated the government-led loan business from the market-driven credit business (Fleisher and Renard, 2011). It provided legal guarantees for the four national specialized banks to become the real commercial banks and to provide market-driven credit business.

In 1984, the Central Committee of the Communist Party of China made it clear that China's socialist economy was a planned commodity economy based on public ownership. Under this system, the banking industry not only increased its vitality but also increased the pressure. On one hand, the credit business developed rapidly - expanding the scope of loans, setting up fixed assets, providing more households loans, issuing more loans for science and technology development. On the other hand, the credit risk of banks was gradually exposed and intensified. Preventing and defusing credit risks have become a top priority for banks. Therefore, Chinese regulators have established the deposit reserve system, bad debt reserve system, deposit system, credit card system and the asset liability management system. These systems constitute the cornerstone of future banking credit risk management (Okazaki, 2017).

\subsection{Market Economy and Credit Risk Management in China From 1994 to 2000}

After nearly 20 years of reform and development, China had formed a socialist market economy system with the four-major state-owned commercial banks working as the backbone of the banking industry. However, as a result of the unsolved problems from the previous planned commodity economy period, it was hard to push forward reform during the early stages of socialist market economy. Meanwhile, the East Asian financial crisis sounded a warning to China's financial industry in 1997(Lin, Tsao and Yang, 2009). The four-major state-owned commercial banks played a major role during this stage. Their main characteristics were as follows.

First, credit financing was still organised by the government, especially after conducting the 'funds to loans policy for state-owned enterprises'. This indicates the transfer from that the Ministry of Finance subsidies to state-owned enterprises to where banks that can grant loans to state-owned enterprises. On one hand, financial subsidies for state-owned enterprises were on the decline. On the other hand, potential subsidies for state-owned enterprises from bank loans were increasing. Of all the subsidies received by state-owned enterprises in 1985, only $24.2 \%$ came from banks, but this data increased to $43.6 \%$ in 1994. At the same time, because of the low profitability and high debt ratio of many state-owned enterprises, they became highly dependent on banks for financing, but it was difficult for them to repay the principal and interest on time. This resulted in a large number of non-performing loans (NPLs) to banks (Chan, 2010).

Secondly, the government had greater intervention with bank operations. Sometimes the government intervened directly in the management of the banks, by means of administrative orders to force banks to lend to firms on the verge of bankruptcy, to make arrangements for laid-off workers, to pay taxes, and even to make up deficits. In some provinces, local governments even ordered banks to lend to firms at the end of year to help firms pay taxes in order to achieve their fiscal revenue targets (Okazaki, 2017).

Thirdly, bank managers started with their own interests to maximize banks' size and costs. On one hand, they were keen to expand the institutions. On the other hand, they were keen to increase the costs of banks, especially the construction of luxury office buildings and training centres which can result in bank profits declining. According to reports from the State Statistical Bureau between 1989 and 1998, the balance of credit assets of the four-major state-owned commercial banks were eleven times higher. However, the total profits grew by only $26 \%$, while the management fees were 8.9 times higher (Umar and Sun, 2016).

Fourthly, the internal management of banks was weak, and there was no effective risk prevention measure. In the banking business, it was common to borrow new loans to repay the old, to charge interests for both credits and loans and to apply for loan extensions. In the non-credit assets, there were problems such as discrepancies between book 
value and actual value and indiscriminate use of loans. In the off-balance sheet business, there were some phenomena such as granting excessive credit (International Monetary Fund, 2014).

In 1992, commercial banks participated in the real estate industry and securities market speculation which led to a chaotic situation in the financial industry. Therefore, the Chinese regulators promulgated the Law of the People's Bank of China and the Law of Chinese Commercial Banks in 1995. The law of commercial banks clearly stipulated that Chinese commercial banks should not engage in the securities market, trusts or insurance industries. For the first time, a systematic legal system was set up for the supervision of commercial banks in china (Wong, 2005).

In 1998, the Chinese commercial banks learned the experience from national commercial banks and loan assets were divided into five categories: normal, concern, secondary, doubt, and loss according to their risk degree. According to the financial status and changes in cash flow of enterprises, banks can now dynamically grasp the changes of credit risk (Chi and $\mathrm{Li}, 2017)$.

\subsection{WTO and Credit Risk Management Tendencies in China During 2001}

After fifteen years of long and arduous negotiations, China gained the entry to the World Trade Organization (WTO) in 2001. China has promised to cancel all geographical restrictions within five years. It gradually cancelled its clients' restrictions on Renminbi business and allowed foreign banks to provide services to all Chinese customers. It now allows foreign banks to set up outlets in cities and their examination and approval conditions are the same as those for the Chinese banks. China also cancelled all existing non-approval policies for foreign banks in terms of the ownership, establishing head offices and setting up branches. Meanwhile, foreign banks and financial institutions were allowed to provide loans to motors and enjoyed the same supervision as Chinese financial institutions. In addition, foreign banks were allowed to provide personal consumption loans to Chinese residents ( $\mathrm{Ji}$ and Thomas, 2002).

\section{Challenges of Chinese Commercial Banks in Managing Risks}

After the entry of foreign banks, the credit risk management of Chinese commercial banks faced severe challenges. First, the competitiveness of Chinese commercial banks, especially state-owned banks, was poor because most of them were state-owned and protected by the government under the old planned economy and had not already finished the transformation to face the fierce competition under the current market economy. According to the reports of Hang Seng Bank of Hong Kong in 2001, its costs only accounted for $24.4 \%$ of total income, while the costs in state-owned banks were around 90\%. The pre-tax earnings per capita of Hang Seng Bank was 1 million 570 thousand Hong Kong dollars, ten times higher than that of the state-owned banks. At the same time, Hang Seng Bank's one-year deposit interest rates ranged from 1.7\% to $2.2 \%$, compared with $3.6 \%$ for state-owned banks. The higher the deposit interest rates range, the lower attractiveness the banks (Cui, 2012).

Second, the capital adequacy ratio was low. In the early 1980s, the Chinese government suspended capital investment in state-owned banks. After the financial crisis in South-east Asia in 1997, the Chinese government issued 270 billion yuan of special treasury bonds to supplement the capital of the four-major state-owned commercial banks, but did not establish a normal capital supply channel for them. For a long time, the capital adequacy ratio of the four state-owned commercial banks did not reach $8 \%$ of the regulatory requirements. At the same time, a large gap existed in the extraction of the reserve for bad debts (Chen, 2003). In 2003, the government permitted commercial banks to issue subordinated bonds to increase their subsidiary capital. In the same year, the Government Council decided to inject $\$ 45$ billion to the Bank of China and China Construction Bank to supplement their capital. In addition, the total capital adequacy ratio of 113 Chinese urban commercial banks was only $1.36 \%$ at the end of 2004 (The Economist, 2004).

Thirdly, the non-performing loan ratio was high. By the end of 2002, the balance of non-performing loans of banking financial institutions was 25,980 billion yuan. This figure did not include a one-time transfer by the government of 1 trillion and 400 billion yuan to commercial banks to deal with non-performing loans between 1999 and 2000. At the end of 2003, the non-performing loan balance of the banking financial institutions was 24,406 billion yuan and the non-performing loan (NPL) ratio was $15.19 \%$. The average non-performing loan ratio of the four-major state-owned commercial banks was $19.74 \%$, while the NPL ratio of the top 100 international banks was only about 5\% (Shih, 2004).

The large number of non-performing loans of Chinese commercial banks was mostly caused by continuous losses in state-owned enterprises and the lack of a united credit rating system shared by banking industry. Loan applications from the state-owned enterprises were usually approved even if they were on the verge of insolvency. Chinese commercial banks would also try to extend loans to state-owned enterprises (Guo, 2012). 
To provide healthy financial system and reduce the high non-performing loans, the Chinese government organised four asset management companies handing for the non-performing loans problem. To be specific, China Cinda Asset Management Company was the first asset management company. It was established in 1999 and reformed as a joint-stock company in 2010. China Cinda aimed to reduce the non-performing loans of commercial banks in China, especially for the non-performing loans with the China Construction Bank (Pierce and Yee, 2001). The other three asset management companies including the Chellona Orient Asset Management Company which received bad assets of the Bank of China; the China Huarong Asset Management Company correspondingly received the bad loans of the Industrial and Commercial Bank of China; and the China Great Wall Asset Management Company correspondingly received the non-performing assets of the Agricultural Bank of China (Ma and Fung, 2002).

Meanwhile, the ideal of developing a centralized credit scoring system attracted the Chinese government's attention. In 2002, at the Sixteenth National Congress of the Chinese Communist Party, this initiative was broadly discussed and resulted in formal legal documents to establish a unified credit rating system. The People's Bank of China played a leading role in this operation (Hornby, 2017).

In addition, in order to establish internationally recognized credit risk regulatory standards, the Chinese commercial banks adjusted the structure of credit assets and improved credit quality in accordance with the Basel III agreement on capital adequacy standards. The Basel III requires that the core capital adequacy ratio of commercial banks be raised from $4 \%$ to $6 \%$, while $2.5 \%$ of protection buffer capital and $2.5 \%$ of countercyclical reserve capital were also required, so the minimum requirement of the entire core capital adequacy ratio is $8.5 \%$. Chinese commercial banks also were to regularly report to the People's Bank of China, shareholders, and creditors on the operation and risk status of their credit assets. This increased the transparency of credit assets (Long and Zhang, 2001).

Since China began to implement stock market reform and the listing of the state-owned commercial banks, related studies about the credit risk of commercial banks have attracted academic attention and different problems in this field have achieved fruitful solutions. However, the fundamental problems are that a large amount of research was limited in the theoretical field while the research on the practical level of commercial banks' risk measurement has been relatively weak (Isanzu, 2017).

\section{Problems in the Credit Risk Management of Chinese Commercial Banks}

Most research on credit risk management of Chinese commercial banks has focused on analysing the existing problems, causes, and countermeasures. Peng, Mo, and Peng (2001) recognised some problems by comparing Chinese commercial banks with those in the Western developed countries in terms of credit risk controlling systems. Compared to the Western commercial banks who separate the loan approval department and the loan business department, the division of responsibilities and powers of these two departments in Chinese commercial banks is not clear. This implies that the internal control system is imperfect. For example, the loan business department pays more attention on profitability than the quality of pre-loan investigation reports. When the loan is overdue, the loan business department will shift the responsibility to the loan approval department, which means the necessary dual regulation becomes a single regulation. In addition, leaders in the loan business department have greater decision-making power than the leaders in the credit approval department. Therefore, the measurement of credit risk is actually subjective and unclear. In terms of credit file management, archives, especially those containing some important information, are incomplete.

Chen (2010) outlined the causes of loan default for Chinese commercial banks. The financial system in China is imperfect and the business credit rating is deteriorating. The efficiency of capital use, such as the conversion rate of savings to credit, is still low. The banking industry cannot share enterprise credit rating information. Similar to the situation which often happens in the UK, some Chinese companies have discovered the supervision loopholes and fled their debtor identities by forming new companies. After China joined the WTO, foreign banks try to grab top quality clients in China, which brings tremendous changes in the borrowers' credit situation for domestic commercial banks. For instance, the advantages of Standard Chartered Bank and Citibank in personal consumption loans have attracted a large number of high-quality white-collar workers in provinces and made many local banks unable to compete with them.

Yan (2004) provided effective suggestions for mitigating the credit risk faced by Chinese commercial banks. Although the customer rating and five level classification of loans have been established, there is still a lack of effective information collection and feedback channels. Therefore, the establishment of effective information collection and processing system is the first step in good credit risk management. Compared with the international commercial banks, the internal rating method of Chinese commercial banks is too simple. An effective internal rating method should be established by banks through referring to the mature international rating models and combining 
these models with the industry and regional characteristics of Chinses enterprises. In order to better implement these suggestions, Chinese commercial banks need to pay attention to the relevant techniques as follows.

\section{Techniques in the Credit Risk Management of Chinese Commercial Banks}

Chinese academics do not pay much attention to research and development of techniques of credit risk management and its applications which are based on the achievements of other countries (Wan, Wang, and Zhang, 2008). Dou and Liu (2008) demonstrated the practical application of the four most typical credit risk measure models, namely the Credit Metrics Model, Credit Portfolio Model, KMV Model and the Credit Risk Plus Model, in South-east Asia such as South Korea and Hong Kong. For example, based on the Credit Metrics Model, commercial banks can separate the core parameters of credit data into several available variables in their actual operation such as the loan threshold interest rate, default recovery rate and the Value at Risk $(\mathrm{VaR})$. Then, they use these parameters to calculate the default distribution of loans in South-east Asia. Liu and Wang (2006) focused their attention on the techniques in the Credit Risk Plus Model. There are three core aspects which should be paid attention to in practical application. This model only need to consider two statuses of loans - whether default or not. Meanwhile, default variables obey Poisson distribution so different loans are independent of each other. In addition, this model considers three kinds of uncertainty: the volatility of the default rate around the average default rate, the scale of loss after loan default and the uncertainty of the average default rate over time.

Thereafter, Cheng, Chu, and Mi (2009) highlighted the related problems when using different estimation techniques to get the possibility of default, the risk exposure and the probability of credit loss. These estimation techniques include the loss distribution simulation method, Monte Carlo simulation and Credit Risk Plus simulation approach. They concluded that these techniques require certain assumptions and complete data. If the assumptions are not met or the data are not comprehensive and true, then the Value at Risk (VaR) obtained by these techniques is not true. In reality, the construction of the internal rating system of Chinese banking industry has just begun, so the data-base for implementing these technologies is poor.

\section{Applicability of Foreign Credit Risk Measurement Models in Chinese Commercial Banks}

The analysis of whether foreign credit risk measurement models can be used in Chinese commercial banks not only provides options for practical operations but also makes the possibility of creating new credit risk controlling models (Ma, Ding, and Zhang, 2006).

Cao and He (2006) considered these credit risk measurement models are based on the background of the foreign market, which is not consistent with the specific situation in China and cannot be used directly. Meanwhile, they argued that these models provide some reference for quantitative analysis of credit risk in China. With the development of credit risk quantification and maturity of various application conditions, the application of credit risk measurement models in Chinese commercial banks is an inevitable trend. In order to realize the feasibility of various credit risk measurement models, Wang (2007) offered some suggestions on the reform of the capital market with an increasing number of listed companies; the upgrade of macro and industry databases (e.g. GDP growth rate, unemployment rate, and exchange rate); and the cooperation between banks' internal rating system and external rating agencies.

\section{Conclusion}

In summary, the relevant research in developed countries can be very important reference point for the credit risk assessment of Chinese commercial banks, but this kind of reference should not be copied without question. (Wang, et al, 2017). Meanwhile, in response to the revision of foreign risk measurement models, Wu, Liu, and Huang (2010) suggested that the banks should consider data adoption, credit rating and market environment and human resources. In terms of data adoption, five indicators have a decisive impact on forecasting default results: the current asset turnover, net asset turnover, asset net interest rate, rate of return on net assets and the total assets growth rate. Banks should pay more attention to these indicators before a firm's loan is issued. In terms of firms' credit rating, the empirical evidence showed that the accuracy of the financial position of firms in the previous year was the highest. Therefore, banks should grasp the latest financial situation of enterprises to improve the prediction accuracy. When using the credit risk measurement models, loan approvers need to understand the limitations of models and use several methods at the same to reduce error.

The entry of foreign commercial banks increased the potential credit risk for the Chinese commercial banks. But it is an opportunity for the commercial banks in China to develop its own credit management mechanisms within the context of Chinese banking environment. It is better for the Chinese commercial banks to understand both global and local banking environment to understand credit risk management within historical context and current Chinese 
situations. Any attempt to follow the model driven credit management system developed by the American or European situation can have disastrous consequences.

\section{References}

Alman, M. (2012, August). Shari'ah Supervisory Board Composition Effects on Islamic Banks' Risk-Taking Behavior. SSRN Electronic Journal. https://doi.org/10.2139/ssrn.2140042

Blanchard, O., Dell'Ariccia, G., \& Mauro, P. (2010). Rethinking Macroeconomic Policy. Rethinking Macroeconomic Policy, 10(3), 2-19.

Cao, D.S., \& He, M.S. (2006). Comparison and reference of commercial bank credit risk model. Finance Research, 2006(10), 90-97.

Chan, M. (2010). Financial Markets of China: Issues and Perspectives. Chinese Economy, 43(6), 4-7. https://doi.org/10.2753/CES1097-1475430601

Chen, J. (2003). Capital adequacy of Chinese banks: Evaluation and enhancement. Journal of Banking Regulation, 4(4), 320-327. https://doi.org/10.1057/palgrave.jbr.2340149

Chen, J. (2016). Out of the shadows and back to the future: CPC and law in China. Asia Pacific Law Review, 24(2), 176-201. https://doi.org/10.1080/10192557.2016.1242922

Chen, W. (2010). Countermeasures to improve the level of credit risk management of commercial banks in China. Financial Economy: Theoretical Edition, 2010(3), 10-12.

Cheng, K., Chu, Z.D., \& Mi, Y. (2009). Research on VaR estimation technology for credit risk of commercial bank credit portfolio. Shanghai Economic Research, 2009(2), 103-111.

Chi, Q., \& Li, W. (2017). Economic policy uncertainty, credit risks and banks' lending decisions: Evidence from Chinese commercial banks. China Journal of Accounting Research, 10(1), 33-50. https://doi.org/10.1016/j.cjar.2016.12.001

Crouhy, M., Galai, D., \& Mark, R. (2014). The essentials of risk management. New York: McGraw-Hill Education.

Cui, Y. (2012). Empirical Test on Building up Competitiveness Appraisal System of Joint Stock Commercial Banks in China. International Journal of Economics and Finance, 4(9). https://doi.org/10.5539/ijef.v4n9p149

Deventer, D., Imai, K., \& Mesler, M. (2005). Advanced Financial Risk Management. Singapore: John Wiley \& Sons.

Dou, W.Z., \& Xi, L. (2008). Evaluating credit risk of bank credit based on Credit Metrics Model. Reform and Strategy, 24(10), 81-84.

Edwin, V.M. (2017). Singapore jails ex-traders; Royal Bank of Canada fined by South Korean court. Retrieved 27 July 2017, from https://www.snl.com/interactivex/article.aspx?id=39574515\&Printable=1\&KPLT=7

Fleisher, B., \& Renard, M. (2011). Symposium: Thirty Years of Reforms: What About Capitalism in China?. China Economic Review, 22(4), 627. https://doi.org/10.1016/j.chieco.2011.09.003

Freixas, X., \& Rochet, J.C. (2008). Microeconomics of Banking (2nd ed.). Cambridge: Massachusetts: MIT Press.

Fu, J.F., Zhu, H.M., Guo, R., \& Sheng, W.J. (2013). The exploration of the localization of science and Technology Bank of China: Take the science and technology branch of Hangzhou bank as an example. China Science and Technology Investment, 2011(11), 45-48.

Grundke, P. (2010). Top-down approaches for integrated risk management: How accurate are they? European Journal of Operational Research, 203(3), 662-672. https://doi.org/10.1016/j.ejor.2009.09.015

Guo, Y.A. (2012). Research on the measurement and control of credit risk of commercial banks in China. Ph.D. thesis, Shandong University.

Hasan, I., Wachtel, P., \& Zhou, M. (2009). Institutional development, financial deepening and economic growth: Evidence from China. Journal of Banking \& Finance, 33(1), 157-170. https://doi.org/10.1016/j.jbankfin.2007.11.016

Hilscher, J., \& Wilson, M. (2016). Credit Ratings and Credit Risk: Is One Measure Enough?. Management Science, 63(10).

Hornby, L. (2017). China changes tack on 'social credit' scheme plan. Retrieved 18 July 2017, from https://www.ft.com/content/f772a9ce-60c4-11e7-91a7-502f7ee26895 
Hsiao-yi, C. (1982). An Introduction to the Historical Commission of the Kuomintang. Chinese Studies in History, 15(3), 46-60. https://doi.org/10.2753/CSH0009-463315030446

International Monetary Fund. (2014). People's Republic of China-Hong Kong Special Administrative Region: Financial Sector Assessment Program-Basel Core Principles for Effective Banking Supervision-Detailed Assessment of Observance. IMF Staff Country Reports, 14(207), 1. https://doi.org/10.5089/9781498372176.002

Isanzu, S.J. (2017). The Impact of Credit Risk on the Financial Performance of Chinese Banks, Journal of International Business Research and Marketing, 2(3), 14-17. https://doi.org/10.18775/jibrm.1849-8558.2015.23.3002

Ji, C., \& Thomas, S. (2002). WTO and China's Financial Services Sector. Journal of Contemporary China, 11(33), 673-682. https://doi.org/10.1080/1067056022000008869

Li, K. (1995). A glossary of political terms of The People's Republic of China. Hong Kong: The Chinese University Press.

Lin, H., Tsao, C., \& Yang, C. (2009). Bank Reforms, Competition and Efficiency in China's Banking System: Are Small City Bank Entrants More Efficient?. China \& World Economy, 17(5), 69-87. https://doi.org/10.1111/j.1749-124X.2009.01167.x

Liu, H.C., \& Wang, L. (2006). Credit Risk Plus Model application in credit risk management of commercial banks. Journal of Yunnan University of Finance and Economics, 22(5), 20-25.

Long, H.M., \& Zhang, W. (2001). Credit risk management of commercial banks: historical changes and development. The Theory and Practice of Finance and Economics, 22(111), 40-43.

Ma, C.Q., Ding, Y., \& Zhang, H. (2006). Study on commercial bank credit risk and its measurement model. Modern Management Science, 2006(10), 5-6.

Ma, G.N., \& Fung, B.S.C. (2002). China's asset management corporations. Bank for International Settlements, 2002(115), 1020-0959.

Mohanty, M. (1998). The New Ideological Banner: Deng Xiaoping Theory. China Report, 34(1), 101-105. https://doi.org/10.1177/000944559803400108

Okazaki, K. (2017). Banking System Reform in China: The Challenges to Improving Its Efficiency in Serving the Real Economy. Asian Economic Policy Review, 12(2), 303-320. https://doi.org/10.1111/aepr.12188

Peng, J.G., Mo, W.G., \& Peng, J. (2001). The characteristics of the modern western commercial bank credit risk management in China and the reference. Clothing Herald, 13(3), 26-30.

Pierce, D., \& Lawrence, Y. (2001, July). China's Bank Asset Management Companies: Gold in Them Thar Hills?. Topics in Chinese Law, O'Melveny \& Myers LLP.

Shih, V. (2004). Dealing with Non-Performing Loans: Political Constraints and Financial Policies in China. The China Quarterly, 180, 922-944. https://doi.org/10.1017/S0305741004000682

The Economist. (2004). A $\$ 45$ billion shot in the arm. Retrieved 18 July 2017, from http://www.economist.com/node/2328008

Tsai, S., Li, G., Wu, C., Zheng, Y., \& Wang, J. (2016). An empirical research on evaluating banks' credit assessment of corporate customers. SpringerPlus, 5(1). https://doi.org/10.1186/s40064-016-3774-0

Umar, M., \& Sun, G. (2016). Non-performing loans (NPLs), liquidity creation, and moral hazard: Case of Chinese banks. China Finance and Economic Review, 4(1). https://doi.org/10.1186/s40589-016-0034-y

Wang, B.X. (2007). Credit risk management models of commercial banks in China compared with the international ones. China Finance and Economic Review, 29(3), 65-70.

Wang, J.C. (2012). Research on Process Management Optimization of bank credit business. Ph.D. thesis, Nanjing University.

Wang, L., \& Xie, X. (2015). Study on the efficiency of medium and long term incentive mechanism of urban commercial banks. Chinese and Foreign Enterprisers, 2013(1), 38-41.

Wang, X. (2003). Banking Reforms and Monetary Policy in the People's Republic of China: Is the Chinese Central Banking System Ready for Joining the WTO? (review). China Review International, 10(2), 399-403. https://doi.org/10.1353/cri.2004.0099 
Wang, X.Y. (2013). Guangdong Nanyue Bank: a rising star: an interview with the chief information officer of Guangdong Nanyue Bank-Mai Zhiwen. Financial Times of Science and Technology, 2013(6), 22-22.

Wang, Y., Wang, W., \& Wang, J. (2017). Credit Risk Management Framework for Rural Commercial Banks in China. Journal of Financial Risk Management, 6(1), 48-65. https://doi.org/10.4236/jfrm.2017.61005

Wilson, C., \& Yang, F. (2016). Shanxi Piaohao and Shanghai Qianzhuang: a comparison of the two main banking systems of nineteenth-century China. Business History, 58(3), 433-452. https://doi.org/10.1080/00076791.2015.1122711

Wong, K. (2005). Law of assembly in China: People's Republic of China vs. Republic of China. International Journal of the Sociology of Law, 33(4), 215-245. https://doi.org/10.1016/j.ijs1.2005.09.002

Wu, X.N., Liu, K.M., \& Huang, A.D. (2010). The dilemma of financial early-warning model and the identification and prevention of bank credit risk. Financial Reform, 2010(1), 43-46.

Yan, Q.M. (2004). Empirical analysis of credit risk VaR of commercial banks in China. Financial Research, 2004(10), 40-47.

Zhang, D., Cai, J., Dickinson, D., \& Kutan, A. (2016). Non-performing loans, moral hazard and regulation of the Chinese commercial banking system. Journal of Banking \& Finance, 63, 48-60. https://doi.org/10.1016/j.jbankfin.2015.11.010

Zhang, H.Y. (2008). Credit Risk Plus Model and credit risk management of Chinese commercial banks. Journal of Jishou University natural science, 28(3), 119-122. 